УДК 070 (477).792: 603.481 «1917»

DOI: https://doi.org/10.33782/eminak2019.4(28).342

\title{
«ГОЛОДНА МАСА СТАЄ ЧИМ РАЗ БІЛЬШЕ АПАТИЧНОЮ, БАЙДУЖОЮ ДО ВСЬОГО...»: ЖИТТЯ ТА ПОВСЯКДЕННЯ ПОЛОНЕНИХ ВОЯКІВ-УКРАЇНЦІВ У ТАБОРІ ФРАЙШТАДТ, АВСТРО-УГОРЩИНА (ЗИМА-ЛІТО 1917 Р.)
}

\author{
Ігор Срібняк \\ Київський університет імені Бориса Грінченка (Київ, Україна) \\ e-mail: i.sribniak@kubg.edu.ua \\ ORCID: https://orcid.org/0000-0001-9750-4958
}

У статті відтворено деякі аспекти життя та повсякдення полонених вояківукраїнців у таборі Фрайштадт (Австро-Угорщина) протягом зими-літа 1917 р. У цей час таборяни потерпали від обмеження норм харчування та використання для приготування їжі невластивих продуктів, наслідком чого їі не можна було споживати. У серпні 1917 р. ситуація з харчуванням загострилась настільки, що полонені вдались до «голодного страйку», відмовляючись приймати приготовлені у таборовій кухні обіди та вечері, обмежуючись лише чаєм і хлібом. Лише завдяки спільним зусиллям президії СВУ та українських активістів у таборі, а також заходам комендатури табору, покликаних поліпшити й урізноманітнити харчування таборян - стало можливим припинити страйк і відновити проведення роботи культурно-національного змісту в Фрайштадті.

Ключові слова: полонені вояки-українці, табір, харчування, украӥнська громада, Фрайштадт, Німеччина

Попри те, що окремі аспекти життєдіяльності полонених вояків-українців у таборі Фрайштадт вже вивчалися кількома дослідниками як у кінці XX - на початку XXI cт. ${ }^{1}$, так і вже останніми роками ${ }^{2}$ - стан харчового забезпечення таборян протягом зими-літа 1917 р. ще не був предметом наукового дослідження. Ця проблема навіть не згадується у такому цінному, в джерельному відношенні, виданні як «Союз визволення України, 1914-1918», яке фактично являє собою збірку спогадів організаторів культурно-освітньої роботи у таборі Фрайштадт ${ }^{3}$. Для об’єктивного висвітлення подій навколо загострення стосунків між австрійською владою з одного боку, й української таборовою громадою Фрайштадту - з іншого, видається важливим за-

\footnotetext{
${ }^{1}$ Срібняк І. Полонені українці в Австро-Угорщині та Німеччині (1914-1920 рр.). Київ, 1999. С. 4171; Срібняк І. Українська громада табору Фрайштадт і державотворчі процеси в Україні 19171918 pр. // Україна в революційних процесах перших десятиліть XX ст. Збірник ІПіЕНД імені І.Ф. Кураса НАН України. Київ, 2007. С. 310-319; Кривошеєва Л.М. Національно-просвітня діяльність Союзу визволення України в таборах військовополонених українців (1914-1918 рр.). Дис. канд. іст. наук за спец. 07.00.01 - Історія України. Запоріжжя, 2009. С. 50-58, 95-101, 133-142.

2 Срібняк I. «Люди с нерусской душой...»: реакція полонених українців та євреїв на відвідини Александрою Романовою табору Фрайштадт на початку 1916 р. // Уманська старовина. 2016. Вип. II. C. 41-48; Срібняк I. «Що ви нам про книжки і науку? Ви нам хліба вистарайтеся...» (українська «пропаганда» в таборі Фрайштадт, Австро-Угорщина у кінці 1914 - на початку 1915 рр.) // Емінак: науковий щоквартальник. Київ-Миколаїв, 2017. № 2 (18) (квітень-червень). Т. 1. С. 39-44; Срібняк I., Голоско С. Діяльність Видавничого товариства імені Івана Франка в таборі полонених українців Фрайштадт (Австро-Угорщина) у 1915-1918 pp. // Історичний меридіан: науковий збірник ЧНУ. Спеціальність «Історія». Чернівці, 2018. Вип. 26-27. С. 203-219.

3 Союз визволення України, 1914-1918. Відень, Нью-Йорк: Червона калина, 1979. 197 с.
} 
лучити до використання матеріали з фонду СВУ й архіву згадуваного табору, які зберігаються у ЦДАВО України та містять надзвичайно цінну джерельну інформацію з досліджуваної проблематики.

На початку 1917 р. українська організація полонених табору Фрайштадт досягла апогею свого розвитку, що відповідно вимагало проведення інституційних змін в їі внутрішньому житті та, зокрема, докорінної реорганізації всіх сторін функціонування української таборової громади на засадах значного розширення прав та обов'язків полонених. Для обговорення та вирішення цього питання 28 січня 1917 р. українською громадою були скликані загальні збори всіх членів таборових організацій, які ухвалили рішення про створення «Головної Української Ради» (ГУР) - керівного осередку («централі») з числа полонених, якій підлягали б усі українські осередки табору. На цих зборах також було ухвалено проект реорганізації всіх таборових структур, які з секцій мали перетворитись на самоврядні статутні товарист$\mathrm{Ba}^{4}$.

Як зазначалось у § 2 статуту «Централі Української організації «Головна Українська Рада» в Фрайштадті», метою її діяльності було «централізувати всю таборову працю, давати їй напрямок, а рівночасно вести контролю над цілою роботою всіх таборових організацій і їх членів». Колективними членами ГУР вважались всі таборові товариства й організації, що існували в таборі, у т.ч.: «Просвітній відділ СВУ», «Суспільно-Просвітній Гурток», Видавниче товариство імені Івана Франка, Драматичне товариство імені Івана Котляревського, товариство «Український Хор» імені Михайла Вербицького, товариство «Просвіта» імені Михайла Драгоманова, кооперативна спілка «Власна Поміч», фотографічне товариство «Світло». Статутом було регламентовано, що у подальшому всі нові організації у таборі можуть утворитись лише за дозволом ГУР5.

До складу ГУР також входили голова, секретар і скарбник, вибрані загальним зборами членів українських організацій на трьохмісячний термін, а також референт (голова Просвітнього відділу або «муж довір'я» від СВУ у разі його відсутності останнього), а також голови і по одному обраному делегату від усіх згадуваних товариств (від чайні - голова і референт від Просвітнього відділу). Для вирішення оперативних питань і виконання ухвал ГУР створювалась президія у складі голови, його заступника, секретаря, скарбника та референта СВУ, які мала регулярно збиратись на свої засідання6.

До обов'язків голови ГУР належало «запоряджувати й управляти фондами, які повстають з грошових вкладів усіх Союзних Товариств» (за винятком «Власної Помочі», яка провадила свою власну касу та бухгалтерію). Як і раніше, у таборі діяла «Центральна Каса», в якій акумулювались всі кошти українських організацій, і з неї ж формувались і бюджети товариств (за винятком «Власної Помочі» і товариства «Світло», які діяли на засадах самоокупності). Правильність витрат з каси контро-

\footnotetext{
4 Організаційні форми культурної праці в таборах полонених // Вістник СВУ (Відень). 1917. 18 лютого. Ч. 138. С. 124-125.

5 Центральний державний архів вищих органів влади та управління України (ЦДАВО України). Ф. 4404. Оп. 1. Спр. 55. Арк. 3.

6 Ibid. Арк. 3-Ззв.
} 
лювала Ревізійна комісія, яка мала щомісячно звітувати перед ГУР

Членами Ради були й два делегати від Просвітнього відділу СВУ в таборі, які мали виконувати здебільшого посередницькі функції між комендатурою табору та полоненими. Проте СВУ залишило за собою верховний провід у культурно-освітньому й організаційному житті української таборової громади, відтак делегати СВУ мали право (хоч це не було письмово регламентовано) вдаватись у разі потреби до екстраординарних дій і, зокрема, призупиняти діяльність ГУР, коли б це могло зашкодити успішному розвою національного життя у таборі.

Після цих реорганізацій полонені українці (через президію ГУР8) отримали можливість практично майже самостійно вирішувати широкий комплекс проблем, пов'язаних з їх таборовим побутом, харчуванням, культурно-просвітнім життям, а почасти і з тимчасовим працевлаштуванням поза табором (коли це не суперечило приписам військового часу). Комендатура табору (комендант - полковник Льонгард) намагалася діяти у тісному контакті з виборним представництвом полонених і Просвітнім відділом СВУ, дієво їм допомагаючи після консультацій (у разі потреби) 3 відповідними службами військового міністерства Австро-Угорщини.

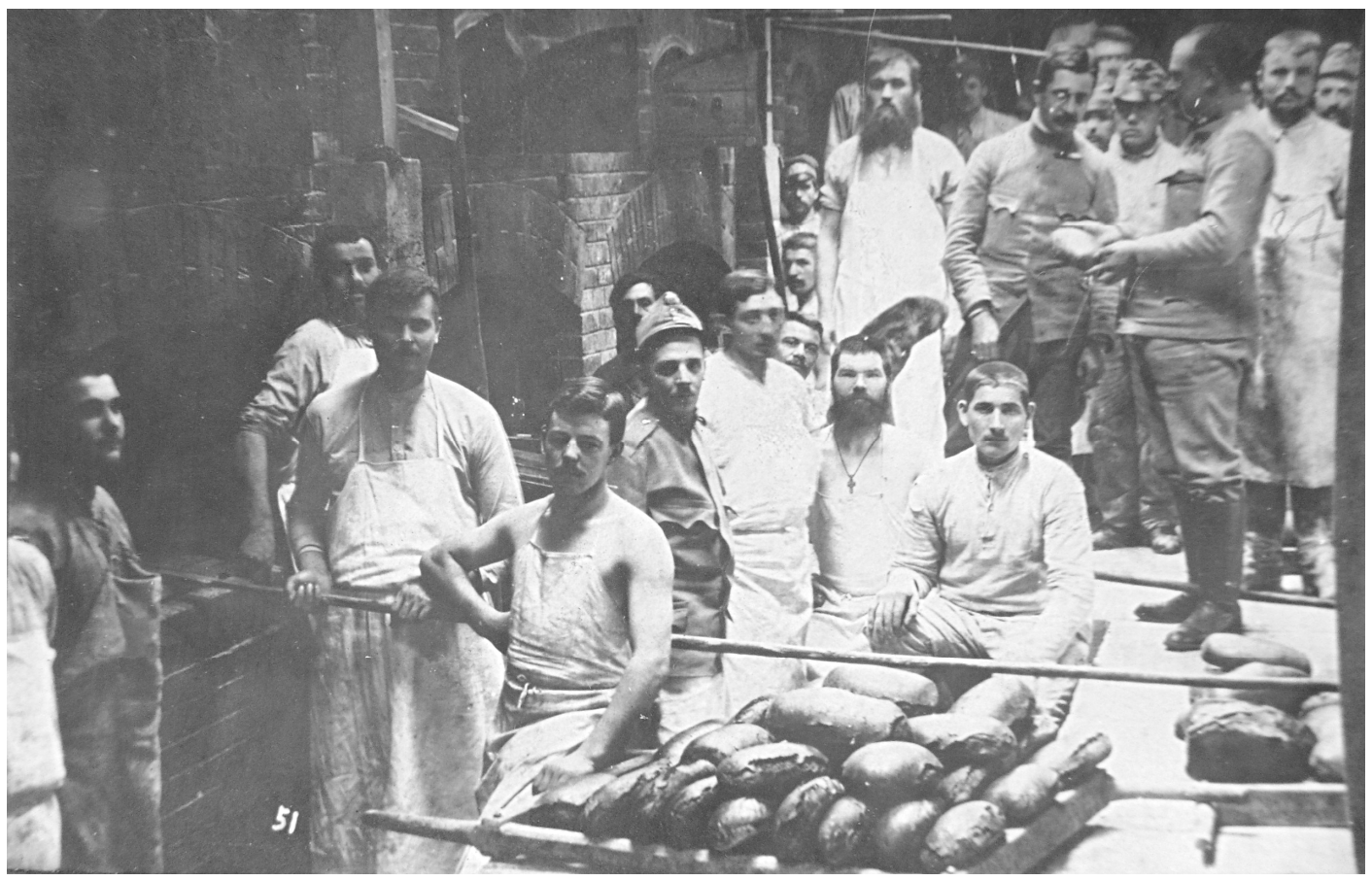

Фото 1. Пекарня табору Фрайштадт, б.д. (ЦДАВО України. Ф. 4404. Оп. 1. Спр. 103. Арк. 37).

Проте спочатку таборова дійсність жодним чином не свідчила про те, що полонені українці дійсно могли скористатись отриманими правами. Побутові умови та хар-

\footnotetext{
7 Ibid. Арк. Ззв.-4.

8 До складу президії Ради першої каденції увійшли: Іван Мороз (голова), Созонт Басок (секретар), Михайло Зимницький (скарбник), д-р Роман Домбчевський (референт Просвітнього відділу СВУ). Див.: ЦДАВО України. Ф. 4405. Оп. 1. Спр. 173. Арк. 6.
} 
чування полонених «фрайштадців» взимку 1916-1917 рр. були настільки незадовільними, що змусило члена Просвітнього відділу СВУ О. Охримовича у своєму листі до А. Жука від 12 лютого 1917 р. сумно зізнатись: комендатура «щадить (економить - Aвт.) вуголь, не дає опалу для наших льокалів (приміщень - Aвт.), так що відпаде правдоподібно багато лекцій та зборів». Наслідком цього «[...]загал полонених (навіть багато з наших найкращих людий) думає тільки про одно: щоби чим скорше вирватися з табору на роботи, де полоненим поводиться багато краще. Серед таких обставин робота в таборі хиба тільки животіє. Голодна маса стає чим раз більше апатичною, байдужою до всього»9.

Про це також свідчить і лист Олекси Лошаченка від 8 лютого 1917 р. до Р. Домбчевського, в якому він просить дати йому відпочинок (у цей час йому було запропоновано поїхати до Німеччина в якості агітатора). Свою відмову брати активну участь у роботі О. Лошаченко аргументував тим, що два роки перебування у таборі забрали у нього всі сили, а на його прохання у таборі про грошову позичку відповіддю були лише обіцянки, і зрештою - залишилися без задоволення. Перебувати в таборі у нього вже не було сил, тому він зголосився поїхати до робітничої команди, і хоча тут йому доводиться «тяжко робити, але за те не голодний (підкреслено в тексті - Aвт.), в таборі ж з голодним черевом, ніяка робота на ум не йде, перешкоджає думка про хліб». О. Лошаченко наполягав, що він «яким українцем я був таким і пребуваю», але його сили були вичерпані повністю. Мав значення і його моральний стан, на якому позначився лист від матері, яка вважала, що її син свідомо потрапив у полон, а відтак повернення додому О. Лошаченка за старої влади в Росії було неможливим, що змушувало його задуматись про свою подальшу долю10.

3 огляду на таку ситуацію, утримати всіх українських активістів у таборі не виявлялося можливим, але від'їзд значного числа українських активістів з табору на роботи мав і позитивні наслідки, спричинившись до суттєвої активізації різних форм культурно-організаційної діяльності серед членів робітничих команд. Як зазначав О. Охримович, табір чим раз тісніше встановлював «відносини з чим раз більшим числом команд, видання наші мають чим раз більший попит». Грошові допомоги, які надсилались з команд до табору - на культурно-освітні цілі - досягли вже суми у 1500 австрійських крон 11.

Отже, полонені не забували про осердя українського життя в Австро-Угорщині Фрайштадт, та не шкодували пересилати до табору невеликі суми, що були зароблені тяжким трудом. Здебільшого, це був денний заробіток полоненого (одна австрійська крона), але важливим було не це, а саме бажання допомогти таборовим організаціям і морально та матеріально підтримати своїх товаришів, які мали залишатись у таборі. В цих умовах видання таборової газети «Розвага» залишалося, на думку О. Охримовича, найважливішою справою, бо остання була найефективнішим засобом для гуртування полонених у складі робітничих команд і двосторонньої комунікації (табір - команди).

Між тим ситуація з проведенням культурно-освітньої роботи у таборі дедалі погіршувалася, підтвердження чого може слугувати наступний лист О. Охримовича до А. Жука від 21 лютого 1917 р.: «в таборі все ще та сама апатія, яка мабуть буде тривати так довго, доки полонені не будуть мати бодай трохи можливіших життєвих

\footnotetext{
9 ЦДАВО України. Ф. 4405. Оп. 1. Спр. 20. Арк. 390зв.

10 ЦДАВО України. Ф. 4404. Оп. 1. Спр. 9. Арк. 358-359зв.

11 ЦДАВО України. Ф. 4405. Оп. 1. Спр. 20. Арк. 391зв.
} 
умов». Особливо дошкуляло те, що «всі пруться на роботи», у т.ч. й переведені з інших таборів з великими труднощами - після звернень СВУ до Військового міністерства Австро-Угорщини. Відтак, на думку О. Охримовича, надалі переводити полонених до Фрайштадту вже не варто, бо останні його ідеалізують (читаючи таборовий часопис «Розвага»).

Прибувши до табору цей контингент полонених починає розуміти, що не знав (i не міг знати, бо у часописі йдеться лише про позитив у Фрайштадті) про темні сторони життя: «примус ходити на роботи, неопалені льокалі для науки, неможність вчитися (бо окрім «вольноопределяющихся»12, всі від рана до ночі працюють), тяжкі умови життя чим в деяких иньших таборах» ${ }^{13}$. Все це призводило до розчарування та породжувало у полонених бажання чим скоріше виїхати на роботи поза табором, від чого, у свою чергу, потерпало культурно-освітнє життя табору. Тому О. Охримович наполягав на тому, що немає жодного сенсу витрачати зусилля для того аби переводити людей до Фрайштадту, бо майже всі вони за кілька тижнів виїжджали на роботи ${ }^{14}$.

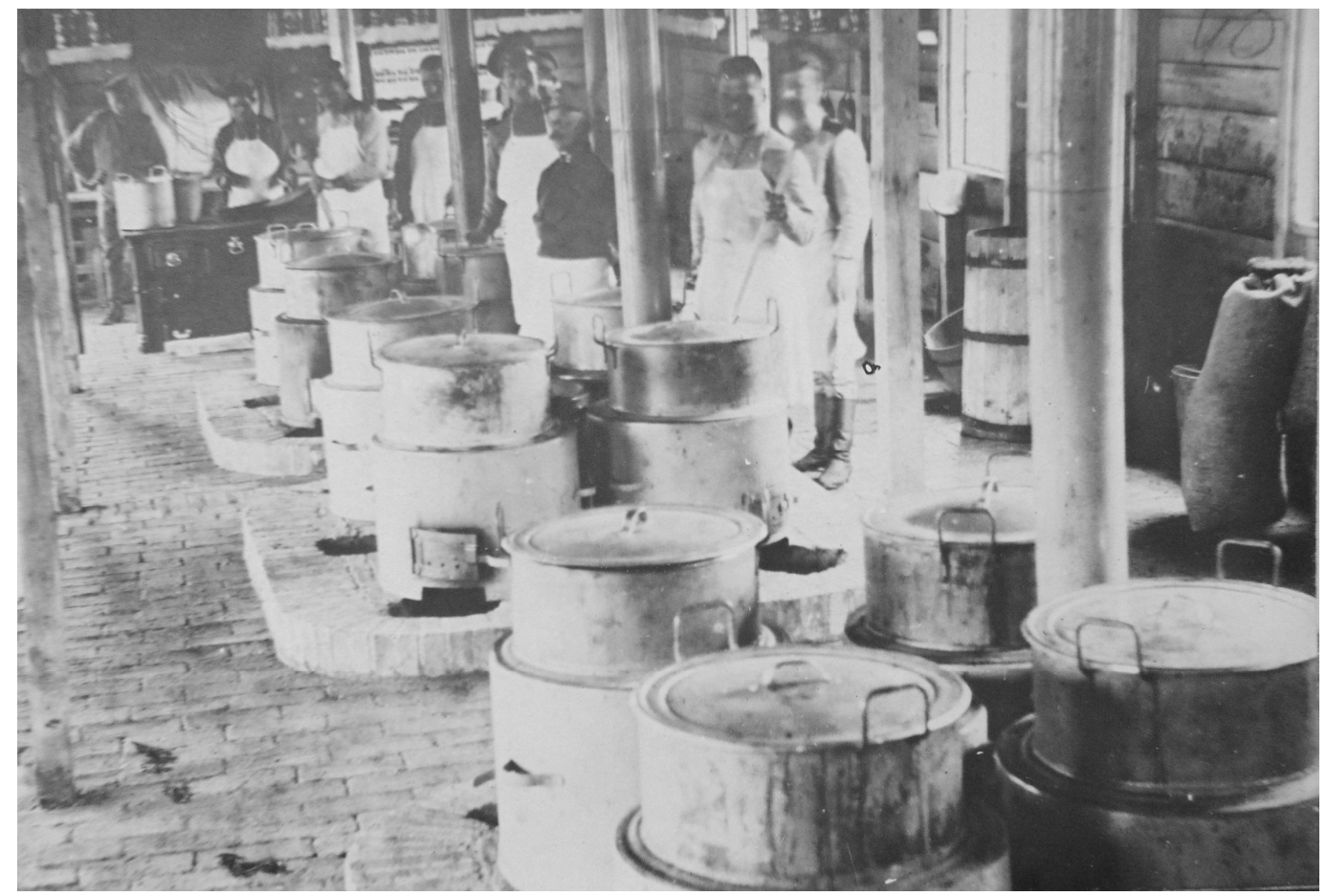

Фото 2. Приміщення для приготування їжі («варочна») табору Фрайштадт, б.д. (ЦДАВО України. Ф. 4404. Оп. 1. Спр. 103. Арк. 40).

У цей час табір втрачав кращих своїх активістів й у зв'язку з тим, що декого з їх числа таємно відряджали через фронт до України зі спеціальними завданнями від

12 Йдеться про військовослужбовців царської армії з певним освітнім цензом, які добровільно зголосились на військову службу і після успішного складання відповідного іспиту отримували перший офіцерський ранг. - Авт.

13 Ibid. Арк. 394-3943в.

14 Ibid. Арк. 395. 
СВУ. Про один з таких фактів йшлося у листі від президії СВУ до Військового міністерства Австро-Угорської імперії (від 6 лютого 1917 р.), коли для проведення української акції на Наддніпрянщині з табору Фрайштадт були відправлені двоє полонених українців (Бабків і Корнатовський). Вони, зокрема, мали поінформувати максимально широкі кола українського суспільства «про ті привілеї, які Австро-Угорщина дає полоненим укр[аїнської] націо[нальності] в таборі Фрайштадт». У цьому випадку СВУ діяв у порозумінні з УСС (до інструктажу та спеціальної підготовки згаданих полонених було залучено П. Франка з Українського легіону) 15.

Ще одна група українців з Фрайштадту, у т.ч. й декілька осіб з числа таборового активу, повернулися додому в рамках обміну інвалідами, що проводився під патронатом Міжнародного Червоного Хреста. Про цю акцію повідомляв А.Жуку 0. Охримович у своєму листі від 28 лютого 1917 р., зазначаючи при цьому ця група українців була доставлена до Петрограду, де їх впродовж двох місяців опитували про побут у Фрайштадті 16 . Така увага до фрайштадців була обумовлена тим, що один з українських поворотців - Лелюх (Лелюхін) - виявився зрадником, донісши російській владі про національну роботу в таборі та давши свідчення про тих осіб, які брали у ній участь ${ }^{17}$. Після цього когось з учорашніх таборян відпустили до України, ще частину комісували з військової служби, кількох осіб залишили на «іспитаніє»18.

Між тим харчовий стан полонених українців у Фрайштадті у січні-лютому 1917 р. продовжував стрімко погіршуватись, ставши ледь не фатальним. Намагаючись хоч якось допомогти таборянам, ГУР вживала всіх можливих заходів для того аби отримати гуманітарну допомогу, для чого звернулась з листами до УЦР, Тимчасового уряду Росії, російського ЧХ і СВУ. І хоча це не дало бажаних наслідків, частину полонених все ж таки вдалося заспокоїти та переконати утриматись від радикальних дій. Найбільша заслуга у цьому належала голові ГУР І. Морозу, який знаходив потрібні слова аби бути почутим таборовим загалом. До того ж, кардинальні політичні зміни у Росії (Лютнева революція), які спричинили ліквідацію царату, активізували загал полонених і відволікли їх від сумних думок, а прихід першого весняного тепла сприяв відносному поліпшенню побутових умов у таборі.

Лютнева революція у Росії спричинила кардинальні зміни в політиці АвстроУгорщини та, зокрема, у ставленні до українських таборових громад. Австрійське військове міністерство вже не мало узгоджувати кожен свій крок з МЗС, коли справа стосувалась полонених українців зі складу російської армії. У березні 1917 р. військова влада Австро-Угорщини пішла на такий безпрецедентний крок як дозвіл на розміщення в окремій секції табору Фрайштадт полонених офіцерів-українців, які висловили таке прохання та були рекомендовані до цього СВУ. Щоправда, зробити це можна було лише після вивезення з табору полонених офіцерів-італійців, з проханням про що президія СВУ кількаразово зверталася до австрійського військового міністерства, аргументуючи це нагальною потребою тіснішого залучення полонених офіцерів-українців до культурно-освітньої праці у Фрайштадті ${ }^{19}$.

У свою чергу президія ГУР також виступала з різними ініціативами: так, зокрема,

15 ЦДАВО України. Ф. 4405. Оп. 1. Спр. 171. Арк. 6.

16 ЦДАВО України. Ф. 4405. Оп. 1. Спр. 20. Арк. 405.

17 Кобець О. Записки полоненого (пригоди і враження учасника Першої світової війни). Мюнхен, 1959. С. 147.

18 ЦДАВО України. Ф. 4405. Оп. 1. Спр. 20. Арк. 405.

19 ЦДАВО України. Ф. 4405. Оп. 1. Спр. 171. Арк. 21-21зв. 
23 березня 1917 р. вона ухвалила рішення про проведення обговорення на таборових вічах і збір підписів під «меморандумом російському революційному правительству», в якому полонені «разом із привітом зазначили [би] своє становище й ожидання». Практично нічого не знаючи про дійсну природу Тимчасового уряду Росії, президія ГУР запропонувала «всім полоненим українських і иньших таборів [...] аби вони зразу розпочали писати в листах до рідні й знайомих, щоб там у Росії всі домогалися негайного заведення демократичного державного ладу, незалежности України, мира і т.и.»20.

3 висоти сьогодення така наївність українських активістів $\epsilon$ просто вражаючою, проте не слід забувати, що полонені фрайштадці були дуже обмежені в отриманні об’єктивної інформації про дійсне політичне обличчя «демократичної» Росії. Зрештою, ця ініціатива не здобула суттєвої підтримки у загалу полонених - до кінця квітня 1917 р. під наказом «Революційному правительству Росії» було зібрано лише 550 підписів полонених (у т.ч. й 15 офіцерів-українців)21. Таким чином, мало хто з числа полонених українців вірив, що цією підписною кампанією можна буде привернути увагу Петрограда до їх долі, тим більше, гарантувати українцям їх національні права у складі демократичної Росії.

Набагато більше полонені переймалися проблемою погіршення продовольчої ситуації в Австро-Угорщині, що безпосередньо та дедалі відчутніше позначалася на харчуванні полонених у Фрайштадті. У лютому-березні 1917 р. воно погіршилося для «фрайштадців» настільки, що щодня 4-5 осіб з їх числа тимчасово втрачали свідомість від голоду та спричиненого цим послаблення організму. Хронічне недоїдання полонених, як повідомляла президія СВУ у своєму листі від 3 квітня 1917 р. до Військового міністерства Австро-Угорщини, робило з них «людей цілком апатичних, а деяких полонених податливими на брехливу ворожу Союзові визв[олення] Укр[аїни] пропаганду»².

Хоча переважна більшість полонених з табору була відправлена на роботи, у таборі залишалося 1600 осіб - здебільшого члени таборових українських організацій, які забезпечували продовження їх діяльності. Частина з них отримувала невелику щоденну грошову допомогу (0,60 австр. крон) для поліпшення харчування з коштів військового міністерства, але надходження цих коштів невдовзі мало припинитись у зв'язку із загальним незадовільним фінансовим станом імперії23.

Попри такі труднощі українська робота у таборі продовжувалась, і навіть охоплювала додаткові категорії полонених у Фрайштадті. 3 огляду на те, що у шпиталі цього табору навесні 1917 р. почалося розміщення полонених інвалідів (з метою їх подальшого відправлення додому в рамках обміну), 3 квітня 1917 р. СВУ звернувся до військового міністерства з проханням на проведення агітаційної роботи серед цієї категорії полонених, тим більше, що до цього часу «управа шпиталю [...] ставила [українській] пропаганді всякі труднощі, з чого користали ворожі Союзові і ідеї визволення України елементи, утворивши з шпиталю базу для контрпропаганди». Задля «єдності табору» та з метою національного освідомлення полонених інвалідів, які ближчим часом повертаються додому і «будучи підготовлені пропагандою можуть вже тепер робить вдома корисну роботу», СВУ просив, зокрема, про уможливлення

20 ЦДАВО України. Ф. 4406. Оп. 1. Спр. 39. Арк. 33.

${ }^{21}$ ЦДАВО України. Ф. 4405. Оп. 1. Спр. 173. Арк. 6.

22 ЦДАВО України. Ф. 4405. Оп. 1. Спр. 171. Арк. 14, 16.

23 Ibid. Арк. 15-16зв. 
доступу до шпиталю для таборового священика о. О. Гнідого 24.

Ще одним наочним проявом сталості діяльності української організації табору стало переобрання у кінці квітня 1917 р. - на час з 28 квітня до 31 липня ц.р. - президії ГУР, для чого були скликані загальні збори всіх таборових організацій. До складу ГУР були обрані ї̈ дотеперішні члени: Іван Мороз (голова), Созонт Басок (секретар), Михайло Зимницький (скарбник), д-р Роман Домбчевський (референт від Просвітнього відділу СВУ) 25.



Фото 3. Роздача їжі полоненим в таборі Фрайштадт, б.д. (ЦДАВО України. Ф. 4404. Оп. 1. Спр. 103. Арк. 41)

Прихід справжнього весняного тепла позитивно позначився на загальному настроєві таборового загалу, на чому наголошував член Просвітнього відділу О. Охримович у своєму листі до А. Жука від 7 травня 1917 р.: «в таборі тепер чудовий настрій (весь табор живе немов одна сім'я)», і хоча у нього «зовсім знищені нерви (наслідком життя серед безнастанного нервового напруження)», і він цілком «виснажений до краю безсонністю», ситуація у таборі набула оптимізму, полонені сподівалися на швидке закінчення війни та своє повернення додому, а, разом, і на демократичні зрушення в Росії та гарантії у ній національних прав українців 26.

Формуванню таких настроїв у таборян великою мірою сприяло те, що у травні 1917 р. тривав збір (в окремій секції табору) офіцерів-українців. Станом на середину травня у Фрайштадті було скупчено вже близько 300 офіцерів-українців, які брали

24 Ibid. Арк. 17, 19-19зв.

${ }^{25}$ ЦДАВО України. Ф. 4405. Оп. 1. Спр. 173. Арк. 6.

26 ЦДАВО України. Ф. 4405. ОП. 1. Спр. 20. Арк. 396зв. 
участь у проведенні культурно-освітньої роботи. Але, окрім «малоросійськості» значної їх частини, несподівано виникла й інша проблема - службовці комендатури табору звинуватили офіцерів-українців у тому, що ті нібито підбурювали полонених солдат до непокори австрійцям. На жаль, автором не було віднайдено документів, які підтвердили би надуманість чи обгрунтованість цих звинувачень, у будь-якому випадку їх наслідком стало рішення про відрядження з Фрайштадту більшості офіцерів-українців (у таборі мало залишитись лише 50 офіцерів)27. Можливо, що свою роль у цьому відіграли й плани військового міністерства Австро-Угорщини українізувати у ближчому часі табір полонених офіцерів у Йозефштадті.

Зрештою, виїзд більшої частини офіцерів-українців не призвів до згортання культурно-освітньої роботи у таборі, бо рівень національної свідомості декого з таборян сягнув такої міри, що у травні 1917 р. був піднесений план таємної відправки полонених до України (для проведення революційно-агітаційної роботи). Крім того, на прохання австрійської влади обговорювались і можливості зарахування декого 3 полонених фрайштадців до складу Українських Січових Стрільців (УСС).

Як йшлося у недатованій чернетці листа, укладеного А. Жуком, «найбільш відповідальними для посилки на Україну з рамена (від - Авт.) Союза $є$ [...] полонені Антоненко, Гончаренко, Навроцький, (Павлик), Цибуля, Короткий - всі з Фрайштадту». Водночас він застерігав, що їх відправлення через фронт або нейтральну країну могли б «відбутись тільки в тім случаю, коли $є$ технічна змога і певність, що люди доїдуть на місця», а також при наявності відповідних коштів. Перед своїм від'їздом «люди ті мусіли б одержати від Союза інструкції, що до місця і характеру роботи, поведеня і пр.». Крім згадуваних осіб А. Жук також називав ще кількох полонених, яких можна було б відправити «на окуповані [українські] землі» - Лазько, Степанович, Вакс і Базаренко (останній перебував у таборі як цивільна особа) ${ }^{28}$.

Також А. Жук запропонував делегувати до складу формації Січових Стрільців 10 полонених українців (у т.ч. Гейко, Овдєєнко, Лошаченко, Мочульський, Мандрика, Івченко, Борисенко, Тятець, Барабаш та Огіль). Направлення названих таборян до УСС мало бути ще санкціоноване окремою ухвалою президії СВУ, після чого ці кандидатури мали бути розглянуті Бойовою управою з метою остаточного рішення. Нарешті А. Жук повідомляв й імена ще 9 полонених українців, які висловили своє бажання увійти до складу УСС: Корнятовський, Бабків, Болбот, Маренич, Почерпайло, Колядка, Плаксивий, Свитенко (всі з Фрайштадту) і Дейнека (з Візельбургу). Найважливішим, на його думку, було те аби всі ці полонені «офіційно (підкреслено в тексті - Aвт.) були прийняті до Січових Стрільців, та щоб їх уживано в пасивній части фронту, а на боєву і за боєву лінію (до Росії) посилати тільки тих, хто до того сам зголоситься» ${ }^{29}$.

Між тим влітку 1917 р. ейфорія від постреволюційних перетворень у Росії та законотворчої активності УЦР у головах полонених поступово «вивітрювалась», бо жодних змін в їх становищі не відбувалося, а продовольча ситуація у таборі неухильно погіршувалась. У цій ситуації ГУР продовжувала багаторазово звертись до різних міжнародних добродійних організацій, але то було тяжкою справою - російські благодійні організації та Тимчасовий уряд надавали мінімальну допомогу українсь-

27 ЦДАВО України. Ф. 4405. Оп. 1. Спр. 172. Арк. 82, 83 (лист від 17 травня 1918 р. д-ра С. СмальСтоцького з табору Фрайштадт до I. Мороза у Відні).

28 ЦДАВО України. Ф. 4405. Оп. 1. Спр. 176. Арк. 9-10.

29 Ibid. 
кому табору та його мешканцям, УЦР же уникала цього через «австро-німецькість» СВУ, міжнародні гуманітарні установи переймались долею своїх співвітчизників і під кінець війни вже майже вичерпали всі свої запаси.

Водночас антиукраїнська агітація у таборі не припинялася, при чому на тлі загострення проблеми з харчуванням. Як писав І. Мороз вже постфактум у своєму листі від 26 серпня 1917 р. до А. Жука, що до казанів зі стравами почали «кидати гарбузи 3 корою, хвостами і бебихами (насіння і нутрощі гарбузів - Aвт.). Незадоволення зростало страшенно. Почалося втікання з табору. Репресії команди (комендатури табору - Aвт.) не мали впливу». У цій ситуації пропозиція коменданта табору «поліпшити» харчування полонених шляхом придбання чергової партії гарбузів цілком логічно зустріло з їх боку категоричне заперечення. Демонстрацією серйозності ситуації у таборі стала одноденна відмова таборян від вечері. Після цього харчування трохи поліпшилось і це тимчасово заспокоїло полонених. Проте «панове «агітатори» вже не вгамовувались «і робили в бараках своє ганебне діло, закликаючи полонених до голодного страйку» ${ }^{30}$.

I. Мороз скликав полонених на віча аби їх хоч трохи заспокоїти та пояснити небезпеку таких дій як голодний страйк. ГУР ухвалила рішення про організацію «Запомогової каси», до якої надходили б кошти від «Чайні» (з їі прибутків) і від «заможних» полонених, а крім того - був запроваджений добровільний податок на пакунки та гроші, які надходили окремим полоненим від рідних. Касою керували виборні представники від кожного бараку і завдяки цьому знову вдалося тимчасово стабілізувати ситуацію у таборі.

До справи заспокоєння полонених долучилась і президія СВУ, яка у своєму заклику до полонених заперечувала факти отримання російськими таборами значних партій продуктів у зв'язку з хаосом, що нібито панував на російській залізниці; так само - СВУ значною мірою безпідставно стверджував, що закупівля продуктів у «третіх» країнах для потреб полонених не може бути здійснена через загальний брак продовольства. Але у липні до табору повернулося кілька полонених, які побували в різних таборах. Вони почали поширювати чутки про те, що «в інших таборах харч значно ліпший ніж в Фрайштадті», що насправді не відповідало дійсності (це стало зрозумілим після кількох поїздок О. Охримовича й о. Омеляна Гнідого до таборів у Мархтренку та Кляйнмюнхена).

«Але факту виписування продуктів поживи з нейтральних держав (за гроші) i надсиланням сухарів із Росії сухарів і інших продуктів», як переповідав слова своїх колег І. Мороз, нема підстав заперечувати, бо «з давніх часів ріжні продукти виписувалися й виписуються з нейтральних держав у досить чималій кількості». Відтак переповідати текст цього звернення СВУ «полоненим нашого табору - значить уводити їх у блуд, підривати довіру до організації і т.ін. 3 Росії продукти таки надходять»31. I члени просвітнього відділу СВУ, яким доводилось бувати в інших таборах, бачили їх на власні очі. Відтак, на думку І. Мороза, слід було змінити акценти, бо «свідома, а найбільш несвідома агітація проти команди і організації набула небезпечного характеру». На жаль, цього не було вчасно зроблено.

Той аргумент I. Мороза, що у цей час голодувала вся Австрія, не сприймався частиною полонених, які хотіли дбати тільки про себе та своє виживання (зрештою, у

\footnotetext{
30 ЦДАВО України. Ф. 4405. Оп. 1. Спр. 20. Арк. 345зв.-346.

31 Ibid. Арк. 345.
} 
цьому їм тяжко дорікати - Aвт.). У своєму листі до невстановленого адресату (ймовірно - А. Жука) від 16 серпня 1917 р. І. Мороз повідомляв про ще одну обставину, яка дуже перешкоджала процесові переконання таборян: відправлення Тимчасовим урядом до російських таборів значних кількостей продуктів (сухарів, сала й ін.) з їх подальшою роздачею. Деяка частина з них закуповувалася у нейтральних країнах через структури Червоного Хреста і також надходила до таборів полонених росіян. Фрайштадт отримував менший обсяг гуманітарної допомоги, бо це був український табір, а крім того до продовольчої кризи в Австро-Угорщині він був забезпечений краще у порівнянні з іншими таборами полонених зі складу російської армії. Провід української громади регулярно звертався до коменданта табору з проханням поліпшити харчування, проте останній кожного разу заявляв, що він не має і не матиме такої можливості ${ }^{32}$.

Як вже зазначалося, влітку 1917 р. ГУР продовжувала вживати «всіх засобів, щоб здержати масу від небезпечних кроків, щоб винайти інші шляхи до поліпшення», зверталась з проханням про допомогу до УЦР, УЧХ, Союзу міст та земств, але вже без жодних наслідків. На початку серпня комендатура табору, у ситуації надзвичайної продовольчої скрути знову вдалась до того, що до казанів зі ставами «почали кидати [...] гарбузи, яких не чистять, а кидають з насінням, бельбухами і верхньою корою». Цей крок австрійців призвів до того, що полонені табору Фрайштадт, за висловом I. Мороза, «впали в цілковиту безнадійність щодо поліпшення свого становища»33.

В силу цієї безвиході фрайштадці зажадали перед комендантом табору приїзду представника австрійського уряду («конзуля»), у відповідь на що останній заявив, що не має такої можливості, але погоджувався прийняти їх претензії у письмовому вигляді та передати їх до Відня. Але полонені вимагали особистої присутності консула у таборі та відмовлялись йти на компроміс. Українська організація опинилась як між двох вогнів - з одного боку комендатура табору, з іншого - загал полонених 34 .

У цій ситуації І. Мороз заявив таборовому загалу, що не поділяє таких методів боротьби, що страйк може призвести до репресій щодо полонених, а крім того - тривала відмова від їжі поставить під загрозу здоров’я та, навіть, саме життя таборян, після чого відмовився брати участь у роботі наради представників бараків, під час якої й було ухвалено рішення про початок страйку. Така позиція І. Мороза була підтримана українським активом табору, що дозволяє стверджувати, що українська організація відмежувалась від страйку, проте із солідарності із зага́лом полонених їі члени пізніше так само відмовлялись отримувати гарячі страви під час обіду та вечері, обмежуючись лише чаєм і хлібом.

Врешті-решт недруги української справи, які ані на день не припиняли своєї деструктивної діяльності, зуміли домогтись свого. Їм вдалось спровокувати таборян до проведення «голодового стайку» на знак протесту проти незадовільного харчування. Страйк розпочався несподівано-раптово 16 серпня, але за наполяганням I. Мороза комендант обіцяв не вживати жодних репресій до вечора наступного дня за умови, що страйк буде припинено зусиллями українського активу табору. Проте поява у таборі о 10 годині ранку роти молодих австрійських солдатів з офіцерами, які вдались до довільних арештів полонених, унеможливила подальший пошук шляхів порозуміння з комендатурою. Того ж дня було заарештовано 20 полонених,

\footnotetext{
32 Ibid. Арк. 339.

33 Ibid. Арк. 339зв.

34 Ibid. Арк. 339-339зв.
} 
причому їх арешт, як згадував І. Мороз у своєму недатованому листі до А. Жука, був обставлений «торжественно» (силами роти солдатів), що було зроблено очевидно для того, аби показати полоненим серйозність намірів комендатури ${ }^{35}$.

Позиція І. Мороза, який закликав до неучасті у страйку, була добре відома комендатурі, проте таборовий австрійський офіцер Плевка піддався нашептам ворогів української справи у таборі та санкціонував його арешт задля дискредитації української організації в таборі. І. Мороза під вартою було доставлено до комендатури, де відбувся його допит. Тоді І. Мороз відчув, що комендант Вінклєр вів до того аби «довести вину організації і т.т. Домбчевського і Охримовича», але вже за короткий час він заявив, що цілком довіряє I. Морозові, а його арешт був безпідставним ${ }^{36}$. Тим не менш він був переміщений до таборового «арештантбараку».

Конфлікт набув загострення й на інституційному рівні - за розпорядженням коменданта були зачинені всі «льокалі для зборів» (загальний барак, бібліотека, «Чайня» й інші українські установи). Всі полонені мали виходити з бараків о 8.00 та йти до роботи, що мала виконуватись таборянами, але приймати обід і вечерю вони й надалі відмовлялись. Такий, фактично мирний, перебіг страйку дратував коменданта, який погрожував розв'язати табір і відправити всіх його мешканців на італійський фронт. Ситуація у Фрайштадті набула такого драматичного характеру, що провідники культурно-освітньої роботи - Р. Домбчевський і О. Охримович з дня на день очікували ліквідації української організації й усієї роботи у таборі.

Готуватись до найгіршого запропонував і I. Мороз, який вважав, що у випадку розв'язання табору слід було за будь-яку ціну зберегти таборову газету «Розвага», «яка є єдиним зв'язком поміж десятками тисяч полонених Українців». На його думку ії видання слід було перенести до табору Дунасердагель (Угорщина), забезпечивши ії відповідним штатом (20 осіб). До цього табору мало бути перевезено і все українське майно (бібліотека, театр тощо). У тому випадку, коли б не вдалося нічого зробити і табір був би ліквідований, І. Мороз просив А. Жука посприяти у звільненні 3 полону його та Федора Івановича Шевченка, які могли б працювати на технічних посадах у редакції однієї з львівських газет ${ }^{37}$.

Слід відзначити, що віденська централя СВУ і, зокрема, А. Жук, не зовсім адекватно реагували на ці події, бо у своєму «Зверненні» до полонених у таборі Фрайштадт (без дати і підпису), закликали таборян припинити голодний страйк, бо буцімто інформація про надходження харчів до інших таборів була неправдивою і, можливо, поширювалася з провокаційною метою. Причинами такого становища СВУ називав брак продовольства у самій Росії та дезорганізацію в ній залізничного сполучення, неможливість закуповувати продукти споживання у нейтральних країнах, а тим більше використовувати їх для поліпшення їжі полонених, коли саме австрійське населення голодувало. У «Зверненні» також безпідставно стверджувалось, що у Фрайштадті з усіх таборів полонених в Австро-Угорщині були створені «найкращі апровізаційні умови», і що полонені з інших таборів «мусіли б завидувати Фрайштадцям» ${ }^{38}(!)$. І хоча СВУ визнавав, що умови ці не були ідеальними, ставало очевидним те, що провід СВУ перебував в омані застарілих уявлень (понад піврічної давнини) щодо ситуації з продовольчим забезпеченням у Фрайштадті, коли його заходами

\footnotetext{
35 Ibid. Арк. 346зв-.347.

36 Ibid. Арк. 348.

37 Ibid. Арк. 340-340зв.

38 Ibid. Арк. 342-344.
} 
для мешканців цього табору дійсно були створені порівняно кращі умови існування у порівнянні з полоненими росіянами.

Зрештою, за участю всіх зацікавлених сторін (СВУ, Військового міністерства Австро-Угорщини, комендатури, проводу ГУР) було знайдено компромісні рішення, які уможливили розблокування протистояння у Фрайштадті. Полонені переконались, що страйк - це шлях у нікуди, натомість комендатура спромоглася якщо не поліпшити харчування, то принаймні зробити вигляд, що вона переймається цією проблемою. У цей час винятково важливим завданням для керівництва СВУ було запобігти розв'язанню українських організацій і загалом табору, а також звільнення зпід арешту І. Мороза. Тому член президії СВУ А. Жук 25 серпня 1917 р. звернувся до полковника (прізвище цього офіцера не було вказано у документі, очевидно йшлося про одного з офіцерів військового міністерства Австро-Угорщини - Aвm.) з власним поясненням причин голодного страйку у Фрайштадті.

Констатувавши у своєму зверненні, що голодовка полонених змусила коменданта «ужити певних репресивних заходів між іншим супроти існуючих в таборі українських організацій», А. Жук звернув увагу австрійського урядовця на те, що «події ті виникли помимо волі (підкреслено у тексті - Aвт.) об’єднаних в українських організаціях полонених». На йому думку важливим було й те, що «ця частина полонених взяла участь в голодівці зі страху перед евентуальними розправами над ними зі сторони неорганізованої маси» (тут А. Жук дещо «згустив фарби», очевидно, що організовані українці приєднались до голодовки не бажаючи порушувати товариську солідарність із загалом таборян - Aвт.) ${ }^{39}$.

На думку А. Жука, попри всі колізії у таборі, «було б не справедливим спиняти дальше функціонування українських таборових організацій і їх пожиточну діяльність». До того ж, І. Мороз з самого початку робив все від нього залежне, «щоби відвернути загал полонених від нерозважливого кроку, на який їх пхали неодвічальні (безвідповідальні - Aвт.) одиниці, які нічого спільного з українською організацією не мають і навіть ворожо до неї ставляться». А. Жук не мав жодних сумнів у тому, що арешт I. Мороза став «результатом якихсь злобних на него доносів, подиктованих бажанням кинути незаслужену тінь на організацію». Далі у листі А. Жук, апелюючи до «прихильного відношення В[ельми]п[оважного] пана Полковника до української справи і велику хіть бути добрим і справедливим опікуном повіреними [йому] людьми», в імені СВУ просив останнього про «уможливлення дальшого ведення праці українських таборових організацій» і звільненні з-під арешту I. Мороза ${ }^{40}$. стави припускати, що це звернення справило потрібне враження, бо того ж дня I. Мороза було звільнено і він повернувся до виконання обов'язків голови ГУР. Таким чином, криза у Фрайштадті була подолана і діяльність усіх українських інституцій у таборі відновилась у повному обсязі.

Отже, реформа таборового життя полонених, яка відбулася на початку 1917 р., перетворила Фрайштадт на «українську республіку» на австрійській землі, бо з цього часу провід табору обирався всіма членами української громади на основі загального, рівного і таємного голосування. Починаючи з цього часу, комендатура табору вже не втручалася у внутрішнє життя полонених українців, а члени Просвітнього відділу СВУ виконували лише дорадчі функції. Внаслідок цього до самостійного ве-

\footnotetext{
39 ЦДАВО України. Ф. 4405. Оп. 1. Спр. 174. Арк. 2.

40 Ibid. Арк. 3-4.
} 
дення полонених перейшли всі організації у таборі (освітні курси, театр, школи, «Запомогова» каса, кооперативна «Чайня», видання газети й ін.).

Але внаслідок дедалі більшого дефіциту продуктів в Австро-Угорщині продовольча ситуація у Фрайштадті невпинно погіршувалась, що врешті-решт призвело до того, що полонені українці цього табору вдались до «голодного страйку». Цей крок поставив під сумнів як проведення української культурно-освітньої роботи у таборі, так і взагалі саме існування Фрайштадту. I тільки конструктивні зусилля проводу СВУ, членів таборового Просвітнього відділу й українського активу, а також об'єктивна зацікавленість австрійської влади врегулювати ситуацію у Фрайштадті дозволили уникнути найгіршого та відновити діяльність всіх українських установ.

Таким чином, ця доба була можливо найскладнішою добою в історії існування української таборової громади у Фрайштадті, що було обумовлено відсутністю дієвої допомоги полоненим українцям з боку УНР (хоча з огляду на державнополітичну трансформацію України у цей час сподіватись на такі кроки від УЦР не доводилось). Відтак таборяни опинились у надзвичайно скрутному становищі, отримуючи лише мінімальну гуманітарну допомогу від російських і міжнародних філантропічних організацій. Але попри всі труднощі та перешкоди розвиток української культурно-освітньої та національно-патріотичної роботи успішно тривав упродовж всього року, завдяки чому в свідомості полонених українців відбулися кардинальні незворотні зміни, які уможливили формування у таборі значної кількості українців з виробленим державницьким мисленням.

\section{REFERENCES}

Kobets, O. (1959). Zapysky polonenoho (pryhody i vrazhennia uchasnyka Pershoi svitovoi viiny) [The Notes of Captive (Adventures and Impressions of a World War I Member)]. Miunkhen [in Ukrainian].

Kryvosheieva, L.M. (2009). Natsionalno-prosvitnia diialnist Soiuzu vyzvolennia Ukrainy $v$ taborakh viiskovopolonenykh ukraintsiv (1914-1918 rr.). [National and educational activity of the Union of Liberation of Ukraine in the camps of Ukrainian prisoners of war (1914-1918)] (Extended abstract of Candidate's thesis). Zaporizhzhia [in Ukrainian].

Sribniak, I. (1999). Poloneni ukraintsi v Avstro-Uhorshchyni ta Nimechchyni (1914-1920 rr.). [Prisoners of Ukrainians in Austria-Hungary and Germany (1914-1920)]. Kyiv [in Ukrainian].

Sribniak, I. (2007). Ukrainska hromada taboru Fraishtadt i derzhavotvorchi protsesy v Ukraini 19171918 rr. [Ukrainian Freistadt Camp Community and State-Building Processes in Ukraine 1917-1918] In: Ukraina v revoliutsiinykh protsesakh pershykh desiatylit XX st. Kyiv, 310-319 [in Ukrainian].

Sribniak, I. (2016). «Liudi s nerusskoi dushoi...»: reaktsiia polonenykh ukraintsiv ta yevreiv na vidvidyny Aleksandroiu Romanovoiu taboru Fraishtadt na pochatku 1916 r. [«People with a nonRussian soul...»: the reaction of captive Ukrainians and Jews to the visit of Aleksandra Romanova to the Freishtadt camp in early 1916]. Umanska starovyna, II, 41-48 [in Ukrainian].

Sribniak, I. (2017). «Shcho vy nam pro knyzhku i nauku? Vy nam khliba vystaraitesia...» («ukrainska «propahanda» v tabori Fraishtadt, Avstro-Uhorshchyna u kintsi 1914 - na pochatku 1915 rr.] [«What do you think about books and science? You can make bread for us...» («Ukrainian propaganda» in the camp of Freistadt, Austria-Hungary at the end of 1914 - early 1915)]. Eminak, 2 (18), Vol. 1, 39-44 [in Ukrainian].

Sribniak, I. \& Holosko, S. (2018). Diialnist Vydavnychoho tovarystva imeni Ivana Franka v tabori polonenykh ukraintsiv Fraishtadt (Avstro-Uhorshchyna) u 1915-1918 rr. [Activities of the Ivan Franko Publishing Society in the Prisoner's of Warcamp «Freistadt» (Austria-Hungary) in 19151918]. Istorychnyi merydian: naukovyi zbirnyk ChNU, (26-27), (pp. 203-219). Chernivtsi [in Ukrainian].

Soiuz vyzvolennia Ukrainy, 1914-1918 (1979). [Liberation Union of Ukraine, 1914-1918]. Viden, NiuYork: Chervona kalyna [in Ukrainian]. 


\section{Ihor Sribniak}

(Borys Grinchenko Kyiv University, Kyiv, Ukraine)

ORCID: https://orcid.org/0000-0001-9750-4958

\section{«The Hungry Mass Becomes More Apathetic, Indifferent to Everything...»: the Life and Daily Routine of Captive Ukrainian Soldiers in Freistadt Camp, Austria- Hungary (Winter-Summer of 1917)}

The paper shows some aspects of life and daily routine of captive Ukrainian soldiers in Freistadt camp (Austria-Hungary) during the winter-summer of 1917. The reform of the captives' camp life, which took place in early 1917, turned Freistadt into «Ukrainian republic» in Austria because since then the camp governing body was elected by all members of the Ukrainian community on the basis of a general, equal and secret vote. From that time on, the camp commandant's office no longer interfered with the internal life of captive Ukrainians, and the members of the Union for the Liberation of Ukraine (SVU) Educational Department performed only advisory functions. As a result, the prisoners started to run all the facilities in the camp: educational courses, theater, schools, «Zapomogova» box office, cooperative «Chainia», publishing of the newspaper, etc.

But with the growing shortage of food in Austria-Hungary, the food situation in Freistadt was deteriorating considerably and steadily, and eventually, it caused the «hunger strike» of the captive Ukrainians. That step called into question both the conducting of Ukrainian cultural and educational work in the camp and the existence of Freistadt itself. Only the constructive efforts of the SVU, the members of the camp's Educational Department and the Ukrainian activists, as well as the strong wish of the Austrian authorities to resolve the situation in Freistadt, allowed to avoid the worst and restore the activity of all Ukrainian facilities.

Thus, 1917 became perhaps the most difficult time in the history of the existence of the Ukrainian camp community in Freistadt, due to the lack of effective assistance to captive Ukrainians from the UNR (although taking into account the process of state and political transformation of Ukraine at that time there was no hope for such steps from the Ukrainian Central Rada - UCR). So the captives found themselves in a very difficult situation, receiving only minimal humanitarian assistance from Russian and international charitable organizations. But despite all the difficulties and obstacles, the development of Ukrainian cultural, educational, and national-patriotic work was successful throughout all the year and led to dramatic irreversible changes in the minds of captive Ukrainians, which made it possible to form a state thinking in a large number of Ukrainians in the camp.

Keywords: captive Ukrainian soldiers, camp, food, Ukrainian community, Freistadt, Germany 